\title{
Common Respiratory Viruses and Pulmonary Mucosal Immunology
}

\author{
David B. Huang
}

The lungs play a critical role in supplying the body's cells with oxygen and in removal of waste products. The lungs are continually exposed to inhaled gases, particulates, and airborne pathogens as a result of daily inhalation of tens of thousands of liters of air. Despite these exposures, the lower airways are able to remain sterile due to the remarkable and efficient host defense systems of the pulmonary mucosal surface. This surface consists of epithelial cells and other cells, such as T cells and dendritic cells, that are able to respond to microbial exposures by activation of humoral and cell-mediated immune responses and the production of inflammatory mediators (i.e., cytokines, chemokines, and antimicrobial peptides). A breakdown in these host defenses, especially when the lungs are exposed to highly virulent organisms or an overwhelming inoculum, can result in an infection of the respiratory tract. Infections of the lung typically occur by aspiration of upper airway resident flora, inhalation of aerosolized material, and metastatic seeding of the lung by infectious agents systemically. This chapter describes the common viral causes of respiratory tract infections and the pulmonary mucosal immunologic response to common respiratory viruses.

\section{Common Viral Causes of Respiratory Tract Infections}

Many viruses can infect the respiratory tract. Respiratory viruses target the ciliated respira- tory epithelium. In most cases, viral infection is limited to the upper airways; however, infections of the lower airway regions occur in a significant number of infected individuals. Worldwide, approximately $90 \%$ of the cases of the "common cold" are caused by viruses and most are seen in the winter months. These viruses are spread from person to person and commonly during hand-to-hand contact. This chapter focuses on the common viral causes of respiratory tract infections: adenovirus, coronavirus including severe acute respiratory syndrome-associated coronavirus (SARS-CoV), influenza virus, rhinovirus, and respiratory syncytial virus (RSV) (Table 6.1). This chapter describes the pathogen, epidemiology, clinical syndromes, pathogenesis, diagnosis, and treatment of each virus.

\section{Adenovirus}

In 1953, adenovirus was discovered after the removal of adenoids and tonsils from children yielded a transmissible cytopathic agent after it was cultured for several weeks (1).Serially passed epithelial cells produced enlarged rounded cells with strands connecting each other from 2 to 5 days after infection. Adenovirus has also been isolated from adenoidal tissues and pulmonary secretions of adults with respiratory tract symptoms of military recruits, and from the eyes of shipyard workers with conjunctivitis. Adenovirus causes approximately $5 \%$ of all upper respiratory infections in children younger than 5 years and $10 \%$ of pneumonias of childhood. 
Table 6.1. Common viral causes of respiratory tract infections

\begin{tabular}{|c|c|c|c|c|c|}
\hline Virus & Epidemiology & Clinical syndrome & Pathogenesis & Diagnosis & Treatment \\
\hline Adenovirus & $\begin{array}{l}\text { Primary infection } \\
\text { takes place in the } \\
\text { first few years } \\
\text { of life. Seasonal } \\
\text { patterns occur in } \\
\text { winter, spring, } \\
\text { and summer. }\end{array}$ & $\begin{array}{l}\text { Bronchiolitis, pneumonia, } \\
\text { pharyngoconjunctival fever, } \\
\text { hemorrhagic cystitis, diarrhea, } \\
\text { central nervous system } \\
\text { disease }\end{array}$ & $\begin{array}{l}\text { Lytic, latent, or } \\
\text { chronic infection } \\
\text { or oncogenic } \\
\text { transformation }\end{array}$ & $\begin{array}{l}\text { Viral isolation, } \\
\text { antigen } \\
\text { detection, } \\
\text { PCR, or } \\
\text { serology }\end{array}$ & Self-limited \\
\hline $\begin{array}{l}\text { Coronavirus } \\
\text { including } \\
\text { SARS- } \\
\text { associated } \\
\text { coronavirus } \\
\text { (SARS-CoV) }\end{array}$ & $\begin{array}{l}\text { Seasonal pattern } \\
\text { occurs in winter } \\
\text { and spring. } \\
\text { SARS-CoV has } \\
\text { first described in } \\
\text { November } 2002 \\
\text { in Guangdong } \\
\text { Province of } \\
\text { China causing } \\
>8000 \text { cases } \\
\text { and } 800 \text { deaths. }\end{array}$ & $\begin{array}{l}\text { Upper and lower respiratory } \\
\text { disease, fever, headache, } \\
\text { chills, mucopurulent nasal } \\
\text { discharge, sore throat, cough, } \\
\text { diarrhea, and neurologic } \\
\text { syndromes; SARS-CoV causes } \\
\text { similar symptoms. SARS-CoV } \\
\text { has an overall case-fatality of } \\
7-17 \% \text { and up to } 50 \% \text { in } \\
\text { persons with underlying } \\
\text { medical condition or age over } \\
65 \text { years. }\end{array}$ & $\begin{array}{l}\text { SARS-CoV can cause } \\
\text { pulmonary } \\
\text { hyaline } \\
\text { membrane } \\
\text { formation, } \\
\text { interstitial } \\
\text { infiltration, and } \\
\text { desquamation } \\
\text { of pneumocytes. }\end{array}$ & $\begin{array}{l}\text { Viral isolation, } \\
\text { antigen } \\
\text { detection, } \\
\text { RT-PCR, or } \\
\text { serology }\end{array}$ & $\begin{array}{l}\text { Self-limited; } \\
\text { steroids may } \\
\text { be of benefit } \\
\text { in patients } \\
\text { infected with } \\
\text { SARS-CoV. }\end{array}$ \\
\hline Influenza virus & $\begin{array}{l}\text { An average attack } \\
\text { rate is } 10-20 \% \\
\text { but may be as } \\
\text { high as } 50 \% \text { in } \\
\text { the young and } \\
\text { the elderly; } 31 \\
\text { pandemics have } \\
\text { occurred. The } \\
\text { 1918-1919 } \\
\text { pandemic } \\
\text { resulted in } 21 \\
\text { million deaths } \\
\text { worldwide. }\end{array}$ & $\begin{array}{l}\text { Fever, chills, headaches, dry } \\
\text { cough, pharyngeal pain, nasal } \\
\text { obstruction, hoarseness, } \\
\text { myalgia, malaise, anorexia, } \\
\text { and ocular symptoms; myositis, } \\
\text { cardiac complications, toxic } \\
\text { shock syndrome, and central } \\
\text { nervous complications can } \\
\text { occur. A secondary bacterial } \\
\text { infection can complicate } \\
\text { influenza infection. }\end{array}$ & $\begin{array}{l}\text { Hemagglutinin and } \\
\text { neuraminidase } \\
\text { are surface } \\
\text { antigens. M1 and } \\
\text { M2 are integral } \\
\text { membrane } \\
\text { proteins. The } \\
\text { incubation } \\
\text { period is } 18 \text { to } \\
72 \text { hours. Diffuse } \\
\text { inflammation of } \\
\text { the upper and } \\
\text { lower respiratory } \\
\text { mucosa. }\end{array}$ & $\begin{array}{l}\text { Viral isolation, } \\
\text { culture in } \\
\text { embryonated } \\
\text { eggs, antigen } \\
\text { detection, } \\
\text { PCR (used in } \\
\text { research } \\
\text { settings), or } \\
\text { serology }\end{array}$ & $\begin{array}{l}\text { M2-inhibitors } \\
\text { (amantadine, } \\
\text { rimantadine) } \\
\text { and } \\
\text { neuraminidase } \\
\text { inhibitors } \\
\text { (zanamavir, } \\
\text { oseltamivir) if } \\
\text { started within } \\
48 \text { hours of } \\
\text { symptoms }\end{array}$ \\
\hline Rhinovirus & $\begin{array}{l}\text { Primary infection } \\
\text { takes place in } \\
\text { the first few } \\
\text { years of life. } \\
\text { Seasonal pattern } \\
\text { occurs in fall, } \\
\text { spring, and } \\
\text { summer. }\end{array}$ & $\begin{array}{l}\text { Nasal, pharyngeal, or lower } \\
\text { respiratory tract involvement; } \\
\text { median duration of } \\
\text { symptoms is } 7 \text { days and up } \\
\text { to } 2 \text { weeks in } 25 \% \text { of } \\
\text { infected persons. }\end{array}$ & $\begin{array}{l}\text { Incubation period } \\
\text { is } 8-10 \text { hours. } \\
\text { Only slight } \\
\text { damage to the } \\
\text { mucosal } \\
\text { epithelium } \\
\text { occurs. }\end{array}$ & $\begin{array}{l}\text { Viral isolation } \\
\text { using cell } \\
\text { culture systems } \\
\text { (WI-38, MRC-5 } \\
\text { strains, M-HeLA } \\
\text { cells), PCR, } \\
\text { and serology }\end{array}$ & Self-limited \\
\hline $\begin{array}{l}\text { Respiratory } \\
\text { syncytial } \\
\text { virus }\end{array}$ & $\begin{array}{l}\text { Primary infection } \\
\text { takes place in the } \\
\text { first few years of } \\
\text { life. Seasonal } \\
\text { pattern occurs in } \\
\text { the winter and } \\
\text { spring. Risk } \\
\text { factors include } \\
\text { young age, male } \\
\text { sex, and lower } \\
\text { socioeconomic } \\
\text { status. }\end{array}$ & $\begin{array}{l}\text { Bronchiolitis, croup, } \\
\text { tracheobronchitis, and } \\
\text { pneumonia; central nervous } \\
\text { system and cardiovascular } \\
\text { symptoms, and rashes are } \\
\text { uncommon manifestations. }\end{array}$ & $\begin{array}{l}\text { Surface proteins } \\
\text { (F, G) are integral } \\
\text { to pathogenesis. } \\
\text { Infection involves } \\
\text { lymphocytic } \\
\text { peribronchiolar } \\
\text { infiltration, } \\
\text { edema of the } \\
\text { bronchiole } \\
\text { epithelium. }\end{array}$ & $\begin{array}{l}\text { Viral isolation, EIA } \\
\text { (sensitivity } \\
60-70 \%, \\
\text { specificity 90- } \\
\text { 95\%), RT-PCR } \\
\text { (used in } \\
\text { research } \\
\text { settings), or } \\
\text { serology }\end{array}$ & $\begin{array}{l}\text { Supportive } \\
\text { treatment; } \\
\text { infants with } \\
\text { severe disease } \\
\text { may benefit } \\
\text { from ribavirin, } \\
\text { bronchodilators, } \\
\text { corticosteroids, } \\
\text { and RSV-IVIG or } \\
\text { palivizumab. }\end{array}$ \\
\hline
\end{tabular}


Adenovirus has the unique characteristic of possessing high oncogenic potential. This was the first human virus to demonstrate oncogenic potential in rodents. Modified adenovirus has been used as vectors for the insertion of genetic material into different types of cells for gene therapy and for immunization against other pathogens. Since the initial description of adenovirus, there have been at least 51 serotypes of adenovirus described based on their hemagglutination pattern of red blood cells, the ability to cause tumors in rodents, and the percentage of guanine plus cytosine content of their DNA (2). However, less than half of these serotypes play a role in human disease. All serotypes have similar morphology and nucleic acid composition, and they produce characteristic cytopathic effect.

Adenoviruses are medium sized, nonenveloped, icosahedron with fiber-like projections, double-stranded DNA viruses with a molecular weight of approximately $23 \times 10^{6}$. The fiber-like projections from the capsomeres are rod-like structures with knobs, and they function as an attachment apparatus for the virus (Fig. 6.1). The adenovirus attaches to a cellular receptor named CAR and are internalized in endosomes, where it undergoes a process of initial uncoating. The virus has an outer protein coat called a capsid. The capsid contains 252 subunits, referred to as

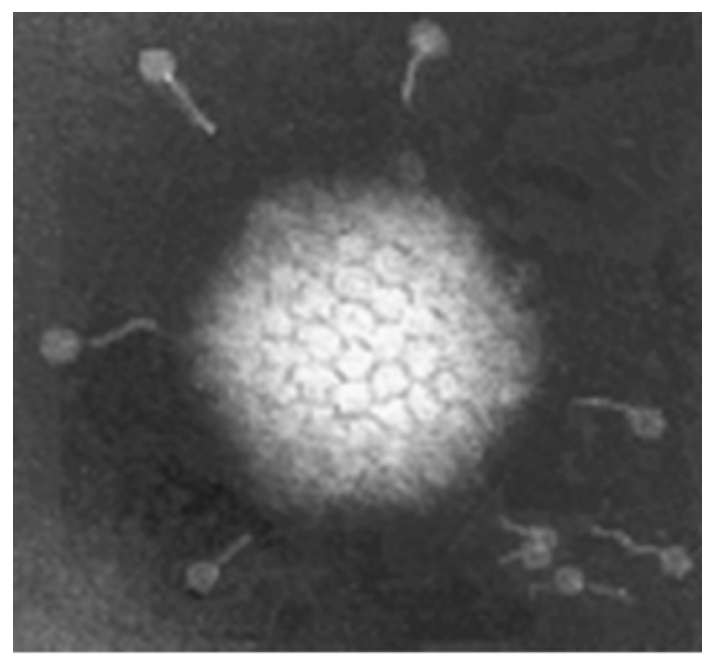

Figure 6.1. Electron microscopy of adenovirus in which six of the 12 vertices are visible. (From www.clinical-virology.org/gallery/images/ em/adenovirus2.gif.) capsomeres, which are arranged in a structure with 20 sides and 12 vertices comprising hexons. Neutralizing antibody is directed at the major type-specific neutralizing epitopes on both the fiber and the hexon.

Adenovirus synthesizes several proteins, which include a family of transforming proteins from the E1A and E1B regions, three proteins from the E2A and E2B regions (responsible for replication of the viral genome), proteins from the $\mathrm{E} 3$ region (which control the host immune and cytokine response to infection), and proteins from the $\mathrm{E} 4$ regions [which facilitate viral messenger RNA (mRNA) transcription].

Most people have experienced a primary infection with adenovirus during their first few years of life (3). Infected individuals with adenovirus may be asymptomatic or the infection may result in a respiratory illness, such as pneumonia, croup, or bronchitis (1). Acute respiratory disease caused by adenovirus was described during conditions of crowding and stress among military recruits during World War II (4). Seasonal patterns of adenovirus most commonly occur in the late winter, spring, and early summer. Adenovirus can cause nonrespiratory tract infections such as gastroenteritis, conjunctivitis, cystitis, and rash. The incubation period of adenovirus is 4 to 5 days. The most common symptoms associated with adenovirus infection are cough, fever, sore throat, and rhinorrhea. These symptoms typically last 3 to 5 days. The classification system of adenovirus serotypes has clinical significance, as there is some association of the serotype, age, and the clinical spectrum of disease. In infants, serotype 7 causes fulminant bronchiolitis and pneumonia. In children, adenovirus serotypes 1,2 , and 4 to 6 are associated with upper respiratory disease. In young adults, particularly military recruits, serotypes 3, 4, and 7 are associated with acute respiratory disease, tracheobronchitis, and pneumonia, and in immunocompromised patients, serotypes $5,31,34,35$, and 39 are associated with pneumonia and dissemination. Transmission of adenovirus can occur by direct contact, fecal-oral transmission, and occasionally waterborne transmission. Adenoviruses are able to survive outside of the body for a prolonged period of time due to their ability to remain stable to chemical and physical agents and adverse $\mathrm{pH}$ conditions.

Adenovirus is capable of a lytic infection (5), a latent or chronic infection (1), or oncogenic 
transformation (6) during their interaction with epithelial cells. A lytic interaction with pulmonary epithelial cells results in cell death by inhibition of both host macromolecular synthesis and transport of cellular mRNA to the cytoplasm. During the lytic interaction, up to one million virions per cell can be released. Natural killer cell and lymphocyte recognition of infected cells elicits a cytokine response and induction of cytotoxic $\mathrm{T}$ cells and neutralizing and nonneutralizing antibodies to adenovirus. Latent or chronic infection with adenovirus involves lymphoid cells. Adenovirus sequences have been found in human lymphocytes and tonsils where a small number of viruses are released over a period of time even in the presence of a neutralizing antibody response. Oncogenic transformation occurs when adenoviral DNA is integrated into and replicated with the host cell's DNA; however, no virions are produced. All three types of interactions with epithelial cells result in virus-specific proteins ( $T$ antigens), which indicate the presence of adenovirus.

A definitive diagnosis of adenovirus infections can be made by antigen detection, polymerase chain reaction (PCR) assay, virus isolation, and serology (7). Because adenovirus can be excreted for prolonged periods of time, isolation of adenovirus does not imply disease. Adenovirus typing is accomplished by hemagglutination-inhibition or neutralization with type-specific antisera. The virus can be cultured from sputum, the nasopharynx, stool, urine, or conjunctival scrapings in monolayers of human epithelial cells. Characteristic cytopathic changes can be visualized after 2 to 5 days. The presence of adenovirus antigens can be detected in samples and tested by immunofluorescence or enzyme-linked immunosorbent assay (ELISA). Serologic diagnosis of adenovirus requires a fourfold rise in antibodies that fix complement, neutralize the virus, or prevent adenoviral hemagglutination by ELISA or by radioimmunoassay.

Most adenovirus infections are self-limited in immunocompetent patients. Symptomatic treatment can be offered. In severe cases among immunocompromised patients, cidofovir, ribavirin, vidarabine, or human immune globulin alone or in combination have been administered with variable success (8-10). However, the overall efficacy of these treatment agents has not been established or thoroughly studied.

\section{Coronavirus Including Severe Acute Respiratory Syndrome-Associated Coronavirus}

Coronavirus was first isolated from chickens in 1937. Tyrrell and Bynoe (11) passaged coronavirus, from nasal wash fluids of patients with common colds, in human ciliated embryonal trachea and nasal epithelium cells in 1965. The medium from these cultures caused respiratory symptoms in volunteers. At about the same time of Tyrell and Bynoe's descriptions of coronavirus, Hamre and Procknow $(12,13)$ described the cytopathic effect of coronavirus 229E isolated from medical students who developed acute respiratory illnesses. A number of animal coronaviruses causing disease have since been described.

Severe acute respiratory syndrome (SARS)associated coronavirus (SARS-CoV) was described in November 2002 (14). This virus was first identified in the Guangdong Province of China, where it subsequently spread to Hong Kong and countries in Southeast Asia, Europe, North America, and eventually throughout the world with more than 8000 cases and 800 deaths by June 2003. The SARS-CoV genome was quickly sequenced and found to be related to previously characterized human and animal coronaviruses (14).

Electron microscopy of a coronavirus shows particles that are medium sized ( 80 to $150 \mathrm{~nm}$ ), pleomorphic with an outer envelope covered with crown-like surface proteins; hence, the name coronavirus (Figs. 6.2 and 6.3). The family Coronaviridae has two genera: Coronavirus and Torovirus. Coronaviruses have a nonsegmented, positive sense, single-stranded, $5^{\prime}$ methylated cap and a $3^{\prime}$ polyadenylated RNA. The RNA codes for a large polyprotein, which forms several nonstructural and structural proteins after being cleaved by virus-encoded proteases. The structural proteins include a surface hemagglutinin-esterase (HE) protein; a surface spike glycoprotein on the virion envelope, which is responsible for receptor binding and cell fusion (S protein), a small envelope protein; a membrane glycoprotein, which is responsible for budding and envelope formation (M); and a nucleocapsid protein complexed with RNA. The $S$ protein mediates attachment to sialic acid, which resides in the plasma membrane of host cells. Antibody to the $\mathrm{S}$ protein neutralizes viral 


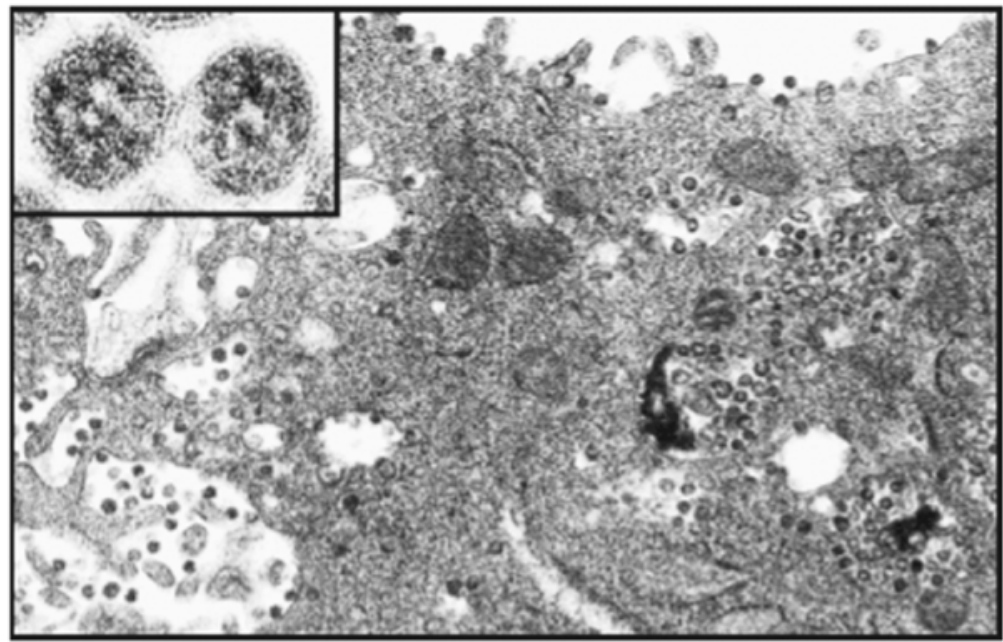

Figure 6.2. Electron microscopy of an infected Vero E6 cell showing coronaviruses within cytoplasmic membrane-bound vacuoles and accumulating on the lining of the surface of the plasma membrane. A higher magnification of the coronaviruses is shown in the inset. (From www.cdc.gov/mmwr/preview/mmwrhtml/mm5212a1.html.)

virion occurs by budding from cytoplasmic vesicles from the membranes of endoplasmic reticulum. Particles are then transferred to the surface of the cell and released from the cell when the cell dies (15).

Over $85 \%$ of adults have antibody to coronavirus OC43 and 229E, the two most studied strains of coronavirus. Respiratory coronaviruses are transmitted from person to person and occur mostly in the winter and spring in coun-
Figure 6.3. Electron microscopy of a coronavirus. (From www.fda.gov/fdac/ features/ 2003/403_sars.html.)

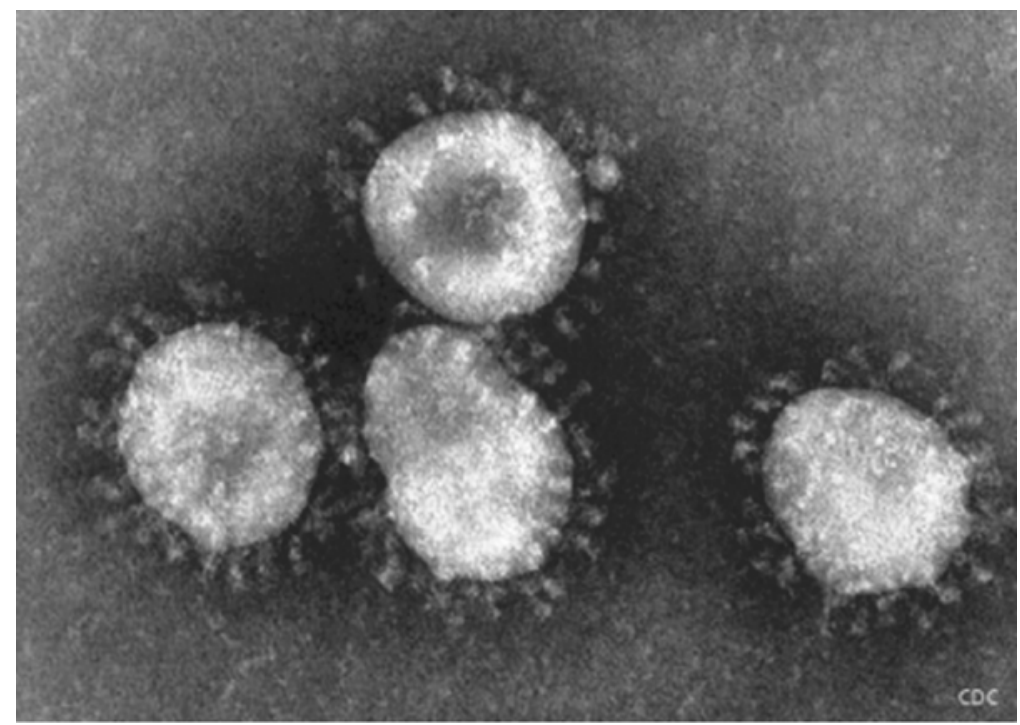


tries with temperate climates. This virus is responsible for $15 \%$ of upper respiratory tract infections in adults. During peak viral activity, respiratory illness due to coronaviruses may be as high as 35\%. In the United States, strains OC43 and 229E are commonly found as causes of large epidemics $(16,17)$. Half of individuals infected with respiratory coronaviruses become ill as evidenced by increased antibody titers. Reinfection likely occurs when there is a rapid decrease in antibody levels after infection.

SARS-CoV causes severe, acute atypical pneumonia in persons who have a clear history of exposure either to a SARS patient or to a setting in which SARS-CoV transmission is occurring (i.e., China, Hong Kong, Hanoi, Taiwan, or Singapore). Epidemiologic studies identified numerous cases occurring in hospitals that involved health care workers, visitors, patients, and family members who had direct contact with infected persons with the SARS-CoV. At the end of the epidemic, in June 2003, the overall case-fatality rate ranged from $7 \%$ to $17 \%$. Among elderly individuals (over the age of 65 years) and persons who had underlying medical conditions, the mortality rate was as high as $50 \%$.

Persons infected with coronavirus develop upper respiratory tract illness and cold symptoms such as fever, headache, malaise, cough, sore throat, mucopurulent nasal discharge, and chills $(11,18)$. Enteric infections, neurologic syndromes, and lower respiratory tract involvement (i.e., pneumonia and pleural effusion) with coronavirus have also been described. The mean duration of symptoms is 7 days with a range of 2 to 18 days. Reinfection occurs because of the antigenic heterogeneity of coronaviruses, and immunity is serotype specific. The elderly are more susceptible to severe respiratory infection compared to younger adults. In persons infected with SARS-CoV, the most common symptoms include fever, headache, malaise, myalgia, nonproductive cough, dyspnea, and diarrhea. Rhinorrhea and sore throat are not commonly reported symptoms among patients with SARS. In $25 \%$ of patients, especially patients over 50 years of age or have some underlying medical condition, pulmonary disease progresses to acute respiratory distress syndrome (ARDS) (19), which has an estimated mortality rate of $10 \%$. Patients infected with the SARS-CoV often have abnormal laboratory values such as lymphopenia, as well as elevated creatine kinase, lactic dehydrogenase, and aspartate aminotransferase levels.

Respiratory coronavirus including SARS-CoV infect a variety of mammals and birds. The number of serotypes of antigenic variation is unknown because most coronavirus isolates cannot be grown in culture. Aerosols of respiratory tract secretions result in coronavirus attachment to the epithelium of the nasopharynx by a virus-receptor interaction. Coronavirus replicates in epithelial cells, resulting in a cytolytic effect on ciliated epithelial cells and release of cytokines and chemokines such as CXCL10/interferon- $\gamma$ (IFN- $\gamma$ )-inducible protein 10 and CCL2/monocyte chemotactic protein 1 (20). These inflammatory mediators are responsible for many of the respiratory symptoms that occur with infection. The incubation period and viral shedding of coronavirus ranges from 3 to 5 days (18). The incubation period of SARS-CoV ranges from 4 to 7 days, with viral shedding reported in some cases over several weeks (21). The pulmonary histology of SARS-CoV infection has been described by the presence of hyaline membrane formation, interstitial infiltration with lymphocytes and mononuclear cells, and desquamation of pneumocytes in the alveolar spaces (22).

Respiratory coronaviruses are isolated from clinical specimens from tracheal or nasopharyngeal epithelium. These viruses can be rapidly detected by antigen detection methods that utilize immunofluorescence of respiratory cells, or enzyme immunoassays of respiratory secretions, or reverse transcriptase PCR (RT-PCR) $(23,24)$. Some strains, such as $229 \mathrm{E}$ and OC43, can be grown in human diploid fibroblast cells lines. SARS-CoV can be isolated from the upper and lower respiratory tract, blood, and stool and urine specimens by RT-PCR and can be grown in the respiratory tract specimens in Vero E6 and fetal rhesus monkey kidney cells. Serum antibodies to SARS-CoV in a single serum specimen or a fourfold or greater increase in SARS-CoV antibody titer between acute- and convalescent-phase serum specimen tests has been used to detect infection with SARS-CoV (25). Immunoglobulin M (IgM) can be detected in cases for a limited period of time and IgG can be detected after the first week of infection. IgA antibody is probably the primary mediator of resistance to coronavirus infections since these infections are initiated in the nasopharynx. 
The treatment of coronaviruses is self-limited and supportive. For the SARS-CoV, anecdotal reports suggest that steroid treatment may be of benefit (26). Interferons have shown in vitro activity against the SARS-CoV but ribavirin has not. SARS-CoV is currently being tested against various antiviral drugs to determine if effective treatment can be found.

\section{Influenza Virus}

One of the first descriptions of an influenza virus outbreak was that of Sydenham in 1679; however, it was not identified until 1933 (27). Influenza attack rates have been reported as high as $40 \%$. A recurrent epidemic of febrile respiratory disease due to influenza virus occurs every 1 to 3 years, and a worldwide pandemic every 10 to 20 years (28). Epidemics typically occur during the winter months and have a characteristic pattern where outbreaks in children are usually followed by influenza-like illness among adults, which is then followed by increased hospital admissions for patients with pneumonia, exacerbation of chronic obstructive pulmonary diseases, and congestive heart failure. An average attack rate of an influenza epidemic is approximately $10 \%$ to $20 \%$, but in certain populations the attack rates may be as high as $50 \%$. Rates of infection are highest among children, and serious illness and death are highest among persons $\geq 65$ years and persons with underlying medical conditions. Influenza is responsible for approximately 36,000 deaths annually in the United States. Pandemic influenza has occurred 31 times thus far, with the greatest pandemic occurring in 1918-1919, causing between 20 and 40 million deaths worldwide (29).

Influenza viruses belong to the family of Orthomyxoviridae and are classified as influenza $\mathrm{A}, \mathrm{B}$, and $\mathrm{C}$ based on their antigenic, structural, genetic, and epidemiologic differences. Influenza A has been most studied and is further characterized into subtypes based on its two surface antigens-hemagglutinin (HA) and neuraminidase (NA). The nomenclature for influenza strains includes the influenza type, place of initial isolation, strain designation, and year of isolation. Influenza virus contains eight separate segments of linear negative-sense single-stranded RNA, and has a ribonucleoprotein core arranged as a helical nucleocapsid that is surrounded by a lipid-containing envelope

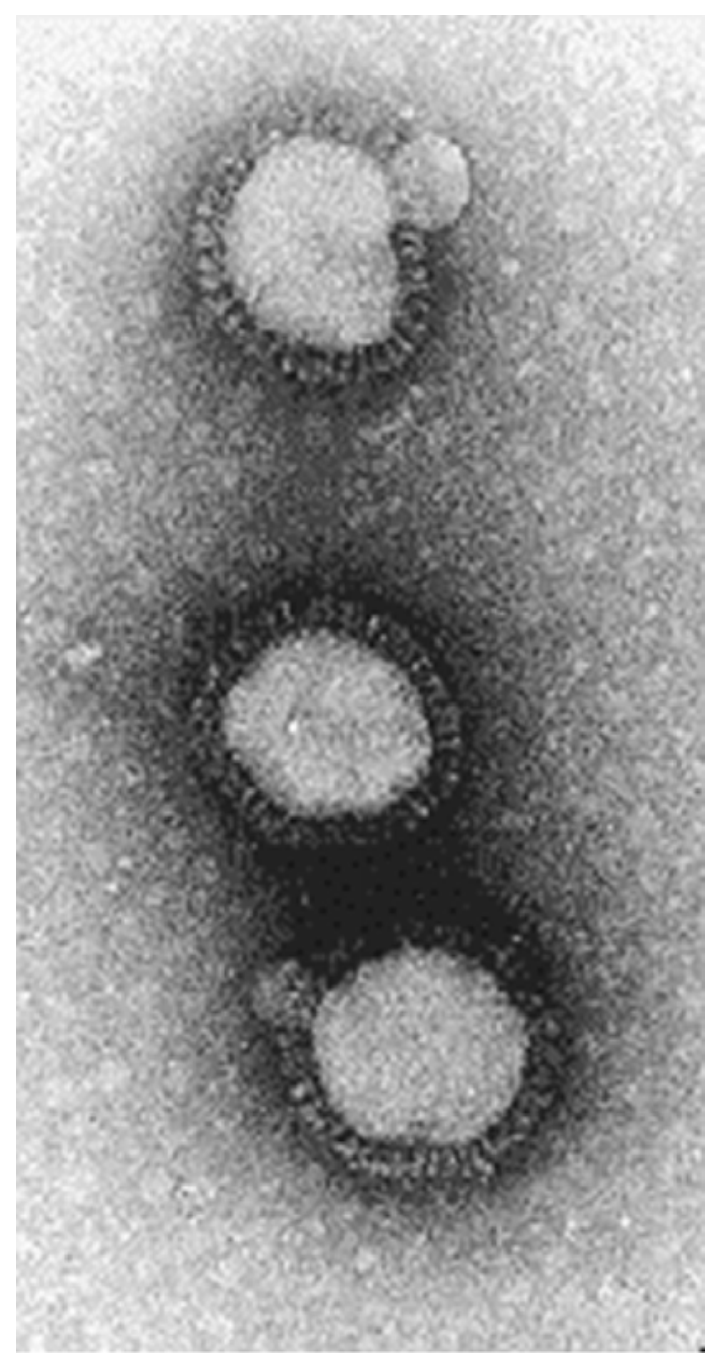

Figure 6.4. Electron microscopy of influenza A virus. (From www. virology.net/Big_Virology/BVRNAortho.html.)

covered with about 500 surface projections that possess HA or NA activity (Fig. 6.4). The HAs extend out from the lipid envelope as a globular rod-shaped head and are involved with attachment of the virus to neuraminic acidcontaining mucopolysaccharide receptors on the cell surface membrane. There are at least 15 described antigenically distinct HAs and at least nine distinct NAs. The NA is mushroom shaped and functions as an enzyme that catalyzes the removal of terminal sialic acids from sialic acid-containing glycoproteins during the early stages of penetration of the virus. Other integral membrane proteins include the M2 protein present in the viral envelope and the M1 protein 
present in the matrix of the virus. Eight discrete nucleocapsid segments exist within the envelope that are associated with viral nucleoprotein and three polymerase proteins (PB1, PB2, and PB3), which are important targets for cross-reactive, viral-specific cytotoxic T lymphocytes.

Influenza causes respiratory-related illnesses that follow a U-shaped epidemic curve with attack rates greatest among the young and the elderly who have lower antibody levels (30). Children are commonly infected due to crowding of children in schoolrooms where aerosol spread is efficient. Influenza epidemics occur mostly in October to April in the Northern Hemisphere and May to September in the Southern Hemisphere. Influenza pandemics are quite variable and occur when there is an emergence of a new virus to which the overall population does not have immunity. Underlying medical disease, such as cardiovascular and pulmonary conditions, diabetes, renal dysfunction, hemoglobinopathies, and immunodeficiencies, are risk factors for severe influenza (31).

A reason for the continued threat of influenza epidemics and pandemics is the unique ability of this virus to alter its antigenic structure, referred to as antigenic variation, of two external glycoproteins HA and NA. The genes that code for HA and NA of influenza A are relatively unstable and continuously undergo mutations that alter their antigenic structure. New influenza variants develop from small antigenic variations known as antigenic drift and large antigenic variations known as antigenic shift. Antigenic drift occurs when relatively minor antigenic changes or an accumulation of point mutations during viral replication occurs at the major antigenic sites on the HA or NA molecule (32). Influenza A virus undergoes antigenic drift more rapidly than influenza $B$ viruses. Antigenic shift results in a new virus to which the population has no immunity. Major antigenic shifts can lead to pandemic influenza.

Infection with the influenza virus occurs by inhalation of small particle aerosols $(<10 \mu \mathrm{m})$ that contain virus. The aerosols are created by sneezing, coughing, and talking. In experimental conditions, nasal drops are infectious at doses of 137 to 300 times the median tissue-culture infective dose $\left(\mathrm{TCID}_{50}\right)$ and 0.6 to $3.0 \mathrm{TCID}_{50}$ by the aerosol route $(33,34)$. The incubation period for influenza is 1 to 4 days, although viral multiplication is detectable within 24 hours. Virus shedding in respiratory secretions disappears after 5 to 10 days in most individuals but can occur up to several months in severely immunocompromised persons. These particles are relatively stable at different temperatures and humidity, although its survival is favored by lower relative humidity and lower temperatures (35). The histopathology of individuals with typical, uncomplicated acute inflammation is characterized by diffuse inflammation (hyperemia and edema) of the mucosa of the larynx, trachea, and bronchi with vacuolization of columnar cells and desquamation of the ciliated columnar epithelium down to the basal layer of cells. Individual cells may show shrinkage, pyknotic nuclei, and a loss of cilia. Viral antigens are found in the epithelial cells but not the basal layers. Lymphocytes and histiocytes are also found in areas with epithelial damage.

In individuals with severe disease, histologic findings include extensive necrotizing tracheobronchitis, with ulceration and sloughing of the bronchial mucosa, extensive hemorrhage, hyaline membrane formation, and a paucity of polymorphonuclear cell infiltrations. Viral replication occurs intracellularly and leads to death of the host cell through decreased host-cell protein synthesis, degradation, and blockage of translation of cellular mRNAs, degradation of coexpressed proteins, and apoptosis $(36,37)$. Cell death due to apoptosis is related to the induction of the Fas antigen by double-stranded RNA during viral replication or poisoning of the mitochondria by a protein PB1-F2, which is encoded by a second reading frame in the $P B 1$ gene (38). The incubation period of influenza virus is 18 to 72 hours. Influenza virus is released several hours prior to cell death and infects nearby epithelial cells and peripheral blood mononuclear cells. Infection of epithelial cells and peripheral blood mononuclear cells elicits release of cytokines that are responsible for systemic symptoms. Infection of peripheral blood mononuclear cells, such as polymorphonuclear leukocytes, lymphocytes, and monocytes, results in defects in these cells' chemotaxis and phagocytosis and a decreased proliferation and co-stimulation by mononuclear cells $(39,40)$. Defects in peripheral blood mononuclear cells are related to virus replication and to the direct toxic effects of certain virus proteins such as the HA, NA, and nucleoprotein.

Infection with influenza virus elicits a humoral and cell-mediated immune response, which is vital in recovery from infection and 
resistance to reinfection (41). There are variable degrees of protection within subtypes but not protection across subtypes. The production of interferon and the generation of cytotoxic lymphocytes best correlate with the recovery from acute influenza. Immunity to reinfection and reduction of the severity of disease with influenza viruses is mediated by antibodies in the serum and the respiratory tract secretions. A systemic antibody response of IgM, IgG, and IgA to influenza virus results in the development of antibody to the glycoproteins HA, NA, and matrix and nucleoproteins (42). Serum IgG neutralizing antibody is the primary mediator of resistance to influenza virus infection. However, antibody to one influenza virus type confers limited or no protection against another influenza virus type. Peak antibody responses are found at 4 to 7 weeks after infection. Antineuraminidase antibody parallels that of hemagglutinin-inhibiting antibodies (HAI) (43) and is the primary method of detecting antigenic relatedness among hemagglutinins of influenza virus. Some studies suggest that a serum HAI titer of $\geq 1: 40$ or a serum neutralizing titer of $\geq 1: 8$ is associated with protection against infection. Antibody to NA can be measured by NA inhibition or ELISA. Anti-NA antibody can provide protection against influenza infection by reducing efficient release of virus from infected cells and decreased severity of illness $(44,45)$. Antibodies to internal proteins (matrix and nucleoproteins) are cross-reactive but not protective against infection. Immunoglobulins $\mathrm{G}$ and $A$ are found in nasal secretions. The IgG to $\mathrm{HA}$ in the nasal secretions is the $\operatorname{IgG}_{1}$ subtype, which is the same subtype found in the serum, suggesting that nasal $\operatorname{IgG}_{1}$ originates from diffusion from the serum (46). Nasal HA-specific IgA is the polymeric and $\operatorname{IgA}_{1}$ subtype. The $\operatorname{IgA}_{1}$ subtype suggests local production and derivation from peripheral lymphoid tissue by memory cells derived from the mucosa.

Cell-mediated responses are important in recovery and resistance to reinfection of influenza. Both CD4 and CD8 T cells effect clearance of influenza A virus. Virus-specific CD8 cytotoxic T lymphocytes recognize class I human leukocyte antigen (HLA) and mediate immunity through lysis of infected cells and expression of antiviral cytokines. CD4 cells recognize epitopes on HA, matrix proteins, and nucleocapsid proteins and stimulate $B$ cells to produce antibody to $\mathrm{HA}$ and NA and antiviral cytokine expression $(47,48)$. Both animal and human studies have found $\mathrm{T}$ helper (Th) 1 and Th2 responses to infection with influenza virus. Infected epithelial cells can be lysed by antibody in the presence of complement, antibodydependent cellular cytotoxicity or by cytotoxic $\mathrm{T}$ lymphocytes (49). Cytotoxic lymphocytes peak at day 14 of infection. Class I-restricted cytotoxic lymphocytes are associated with reduced duration and level of influenza A virus replication in epithelial cells (50).

Infection with influenza can present different complications. The first signs and symptoms of influenza infection are an abrupt onset of fever $\left(37.7^{\circ} \mathrm{C}\right)$ and a dry cough. Uncomplicated influenza infection is characterized by fever, chills, headaches, dry cough, pharyngeal pain, nasal obstruction, hoarseness, myalgia, malaise, anorexia, and ocular symptoms. Otitis media, nausea, and vomiting are commonly reported among children with influenza illness. Influenza illness and symptoms typically resolve over several days for most individuals. Cough and malaise may persist for 2 weeks or more. Primary influenza viral pneumonia and secondary bacterial infection are possible pulmonary complications of influenza infection. Primary influenza viral pneumonia occurs among susceptible persons with underlying cardiovascular and pulmonary disease. These patients have a relentless progression from classic 3-day influenza and have bilateral findings on physical examination and a normal flora sputum bacteriology. Secondary bacterial pneumonia occurs among older patients ( $>65$ years) with underlying pulmonary, cardiac, metabolic, or other disease, followed by a period of improvement within approximately 1 to 2 weeks and then a recrudescence of symptoms of fever with signs and symptoms of bacterial pneumonia. Secondary bacterial infection likely occurs from direct physical damage to bronchial epithelium and impairment of normal ciliary activity in physical clearance of bacteria from the lung. Gram stain and culture of sputum of these individuals most commonly reveal Staphylococcus aureus, Streptococcus pneumoniae, and Haemophilus influenzae. Nonpulmonary complications have also been described with influenza, such as myositis, cardiac complication (myocarditis and pericarditis), toxic shock syndrome, central nervous system complications (Guillain-Barré syndrome, transverse myelitis, and encephalopathy) and Reye's syndrome. 
The sensitivity and specificity of the clinical diagnosis of influenza and influenza-like illness compared to viral culture range from $63 \%$ to $78 \%$ and $55 \%$ to $71 \%$, respectively. Influenza infection is definitively diagnosed by isolation of virus or detection of viral antigen in respiratory secretions, nasal swab specimens, throat swab specimens, nasal washes, or combined nose and throat swab specimens. Incubation of the virus onto rhesus monkey kidney, cynomolgus monkey kidney, or Madin-Darby canine kidney cell line can produce a characteristic cytopathic effect. Influenza virus can be cultured on embryonated eggs and detected within 3 to 7 days (51). Rapid detection of viral antigens in respiratory secretions can be performed with enzyme immunoassay and direct immunofluorescenceDirectigen Flu $\mathrm{A}+\mathrm{B}$ (Becton-Dickenson, Cockeysville, MO), Flu OIA (Biostar, Boulder, CO), QuickVue Influenza A+B test (Quide Corp, San Diego, CA), and ZstatFlu (ZymeTX, Oklahoma City, OK). These tests have varied sensitivities of $40 \%$ to $80 \%$ and specificities of $85 \%$ to $100 \%$ compared to cell culture (52-55). These tests vary in complexity and in the skill and time required for performance and interpretation. Sensitivity appears to be improved with nasopharyngeal swabs and aspirates compared with throat swabs and gargles. Nucleic acid hybridization and PCR amplification have been used in the research setting and offer a higher sensitivity at the cost of being more labor intensive and technically demanding. Serologic tests by using complement fixation and hemagglutination inhibition, consisting of both acute and convalescent sera, are available for making a retrospective diagnosis of influenza.

The treatment of persons infected with susceptible influenza isolates includes M2 inhibitors (amantadine and rimantadine) and neuraminidase inhibitors (zanamivir and oseltamivir). The Centers for Disease Control and Prevention recommends that any person experiencing a potentially life-threatening influenza-related illness or any person at high risk for serious complication of influenza and who is within the first 2 days of illness onset should be treated with antiviral medications (56). Both M2 inhibitors, amantadine and rimantadine, have been shown to be effective in experimentally induced and naturally occurring influenza A virus infection. Resistant viruses have been seen in less than $1 \%$ of unexposed individuals (57-59). The M2 inhibitors inhibit the M2 ion channel activity of susceptible viruses. The M2 ion channel is responsible for acidifying the interior of the virus, disrupting the interaction between the matrix and nucleoproteins, and allowing the ribonucleoproteins to be transported to the nucleus where replication occurs (60). The most common side effects of amantadine are central nervous system related (insomnia, dizziness, and difficulty in concentration). Neuraminidase inhibitors have been shown to be effective in human experimental challenge models and clinical trials. Viruses with reduced susceptibility to oseltamivir have been isolated in $1 \%$ of adults and $6 \%$ of pediatric children. Neuraminidase cleaves terminal sialic acid from sialic acid-containing glycoprotein that serves as host receptors for attachment of influenza virus and facilitates the penetration of virus through secretions in the respiratory tract, which are rich in sialic acid-containing macromolecules $(61,62)$. Neuraminidase inhibitors are generally well tolerated. The most common side effects of the neuraminidase inhibitors are related to gastrointestinal symptoms.

\section{Rhinovirus}

The infectious nature of colds was described in 1914 by Kruse. Volunteer studies with intranasal instillation of bacteria-free filtrates of nasal secretions from cold sufferers into healthy subjects resulted in cold-like symptoms in these individuals (63). It was not until the 1940s that rhinovirus was isolated from the nasal secretions of cold sufferers (64). Rhinovirus is derived from the Greek root rhin meaning nose. Since the 1950 s, research on isolation and characterization of rhinovirus, development of a highly sensitive human embryonic lung cell line (65), a classification system for known rhinovirus and immunotypes (66), and epidemiologic studies have demonstrated rhinovirus as a cause of the common cold (67). Rhinoviruses are estimated to cause up to $35 \%$ of all adult colds and occur mostly in early fall, spring, and summer.

Rhinoviruses are single-stranded, positivesense RNA viruses, belong to the Picornaviridae family, and contain four structural proteins that have exterior projections that interact with neutralizing antibodies VP1, VP2, VP3, and VP4. These structural proteins from a nonenveloped capsid with icosahedral symmetry. Rhinovirus also contains nonstructural proteins including 
two proteases with specific viral cleavage sites, an RNA-dependent RNA polymerase, and a small protein covalently bound to the $5^{\prime}$ end of the viral RNA designated as VPg. There are 12 capsomers per nucleocapsid. A deep conserved hydrophobic cleft on the viral surface functions in maintaining the structural integrity of the viral capsid and in facilitating the conformational changes for uncoating of viral RNA. The $5^{\prime}$ end of the genome has a genome-linked protein and the $3^{\prime}$ end has a polyadenylated tract. Rhinoviruses are similar to enteroviruses with $40 \%$ to $60 \%$ homology between their genomes. There are more than 110 distinct rhinovirus types reflecting the chronology of isolation of the prototypic strains of each serotype (66).

Rhinoviruses are susceptible to inactivation by acid $(\mathrm{pH}<5)$ and a higher density in cesium chloride gradients, which distinguishes them from enteroviruses. These viruses are resistant to organic solvents such as ether and chloroform, and other chemicals such as trichlorofluoroethane, ethanol, and weak phenol. Rhinovirus grows best at temperatures of $33^{\circ}$ to $35^{\circ} \mathrm{C}$, the temperature inside the human nose and large airways (68). Rhinovirus serotypes are based on their receptor specificity. The major group (80\%) of rhinovirus utilizes the leukocyte attachment protein known as intercellular adhesion molecule-1 (ICAM-1, CD54) receptor, a member of the immunoglobulin superfamily (69). It is found on most cells of human origin including HeLa cells, fibroblasts, and cells in the respiratory epithelium. A minority of rhinoviruses bind to low-density lipoprotein receptor.

Worldwide, infections with rhinovirus occur in early childhood and continue throughout life. During childhood and adolescence, antibody levels to rhinovirus are rapidly acquired; they peak in young adulthood and begin to decline and then remain constant throughout adulthood $(70,71)$. Military recruits often encounter respiratory disease in the form of rhinovirus due to the close contact with others in crowded quarters, which allows exposure to infections secretions over a short distance (72). Volunteer studies have shown that effective transmission occurs with infected nasal secretions spread from hand to hand and exposure to fomites followed by autoinoculation of the nasal and conjunctiva mucosa. The aerosol route may also be a means for rhinovirus transmission; however, studies have shown that under ordinary indoor conditions of $70^{\circ} \mathrm{F}$ and $40 \%$ relative humidity, rhinovirus in aerosol is rapidly inactivated (73). The annual seasonal pattern of rhinovirus infection peaks in the fall, with a smaller peak in March, April, and May (70,71). These seasonal patterns can be partially explained by changes in living conditions, and because rhinoviruses survive better under conditions of high relative humidity. In some studies, rhinovirus is recovered in cell cultures in $25 \%$ of patients with colds and in up to $50 \%$ by the combination of cultures and PCR methods (74). Infection rates of rhinovirus range from 1.2 infections per personyear in children up to 1 year of age to 0.7 in young adults $(12,13)$. Transmission of this virus occurs mostly in the home setting, schools, and day-care centers by school-aged children. Secondary transmission occurs in young siblings and mothers, and attack rates have ranged from $25 \%$ to $70 \%$ (75). Other conditions that may lead to increased susceptibility include fatigue, emotional stress, poor nutrition, smoking, or living or working in crowded conditions.

The clinical manifestations of rhinovirus infection can be broadly classified into nasal, pharyngeal, or lower respiratory involvement, and include watery eyes, malaise, anorexia, rhinorrhea, nasal obstructions, sore throat, cough, sneezing, and hoarseness, but fever is uncommon. The incubation period is 24 to 72 hours following deposition of virus in the nasopharynx. The median duration of these symptoms is 7 days and up to 2 weeks in $25 \%$ of infected persons. Usually virus can be shed for 7 to 10 days, but there is documentation of shedding for several weeks.

Rhinovirus has a 95\% infection rate in volunteer challenge studies. According to these studies, rhinovirus replicates in nasal passages and can be detected in the nasal secretions of volunteers as early as 8 to 10 hours, with viral shedding peaking on the second and third day (76). Replication of rhinovirus occurs in ciliated epithelial cells, and cell death results in large quantities of protein including fibrinogen released from the mucous membrane of the nose. Histologic examination of the nasal mucous membranes reveals only slight damage to the epithelium. This damage elicits release of inflammatory mediators such as interleukin-1 (IL-1), IL-6, IL-8, and IL-16 and other mediators such as bradykinin, lysyl-bradykinin, prostaglandin, histamine, and RANTES (regulated 
on activation, normal T-cell expressed and secreted) (77). Histamine increases the blood flow to the infected cells and causes swelling, congestion, and increased mucus production. Serum neutralizing antibodies IgM, IgA, and IgG are produced in nasal passages during infection with rhinovirus $(78,79)$. These antibodies provide protection against reinfection with the same serotype. IgA antibody is however the primary mediator of resistance to rhinovirus.

Rhinovirus is usually diagnosed by clinical suspicion. Rhinovirus can be isolated from nasal secretions, and the yield can be improved when the secretions are collected directly or are washed from the mucosal surface with a physiologic salt solution. Definitive diagnosis of a rhinovirus infection requires viral identification in cell culture systems such as human embryonic lung cell line (WI-38 and MRC-5 strains), HEp-2, and M-HeLA cells at $33^{\circ}$ to $34^{\circ} \mathrm{C}$. The cytopathic effect usually occurs within 2 to 6 days. Polymerase chain reaction with nucleic acid probes is being increasingly used to identify rhinovirus (80). Serodiagnosis of rhinovirus infection has been done with a neutralization test; however, this technique cannot be used on a routine basis due to the multiplicity of rhinovirus types.

The treatment of rhinovirus is supportive, with a combination of a first-generation antihistamine and a nonsteroidal antiinflammatory drug (81). Supportive management also includes rest, hydration, decongestants, saline gargles, and cough suppressants. These supportive treatments may relieve the symptoms of sneezing, runny nose, itchy eyes, and congestion. There are currently no antiviral therapies available for rhinovirus infection.

\section{Respiratory Syncytial Virus}

Respiratory syncytial virus (RSV) was first described in 1956 by Morris and colleagues (82). They identified a chimpanzee coryza agent (CCA) from a chimpanzee suffering from a cold. Later, an indistinguishable strain was isolated from humans with respiratory illness and increases in the specific neutralizing antibody to CCA were found. Epidemiologic studies have found that $95 \%$ of children have antibodies to CCA by age 2, and the CCA virus was subsequently renamed respiratory syncytial virus based on its clinical and laboratory manifesta- tions (83). It is the most common cause of lower respiratory tract infection in infants. In older children and adults, it is a common cause of upper respiratory tract infection. Most persons have experienced infection with this virus within the first few years of life as evidenced by serology. In children under 1 year of age, the yearly attack rate for RSV lower respiratory tract disease has been estimated to be 23 per 100 (84).

Respiratory syncytial virus belongs to the Paramyxoviridae family. This virus does not possess hemagglutinin and neuraminidase activity. It is divided into two major groups, A and $B(85)$. The antigenic relatedness between the two groups is $25 \%$. The major difference between the two groups is the variability in the $\mathrm{G}, \mathrm{F}, \mathrm{SH}$, and NS1 proteins. Both major groups, $\mathrm{A}$ and $\mathrm{B}$, are found to be circulating simultaneously during outbreaks. Respiratory syncytial virus is an enveloped, nonsegmented, single-stranded, negative-sense RNA virus. The RNA encodes for several proteins, of which three are associated with the nucleocapsid, five with the envelope, three with the glycosylated transmembrane surface proteins (F, G, and SH), M and M2 with nonglycosylated matrix proteins, and two glycosylated surface proteins ( $F$ and $G$ ) that are integral in the infectivity and pathogenesis of RSV. The F protein is responsible for viral penetration by fusing viral and cellular membranes. The $G$ protein is responsible for mediating the attachment of the virus to host cells. The viral envelope has a membrane derived from the plasma membrane of host cells and a transmembrane surface with several glycoprotein spikes. Respiratory syncytial virus is unstable in the environment and does not withstand temperature and $\mathrm{pH}$ changes (86). It is stable on nonporous surfaces for 3 to 30 hours and porous surfaces for less than 1 hour, and its optimal $\mathrm{pH}$ is 7.5 . It is readily inactivated with soap, water, and disinfectants.

Respiratory syncytial virus is found in all geographic areas of differing climates every year (87). Seasonal outbreaks tend to occur in the winter or spring in the United States. In northern tropical areas, RSV infection is associated with an increase in rainfall and a decrease in temperature. In the southern tropical areas, RSV is associated with a decrease in rainfall and in temperature. Respiratory syncytial virus infection in children causes bronchiolitis, croup, tracheobronchitis, and pneumonia. Respiratory syncytial virus is rarely found $(0.3 \%)$ in children 
without respiratory disease (88). It is transmitted by respiratory secretions through close contact with infected persons or contaminated objects. Infection occurs when infectious material contacts the mucous membranes of the eyes, mouth, or nose, or possibly by inhalation of infectious droplets. Risk factors for RSV disease are age (severest disease occurs among infants), sex (males are affected more than females), and socioeconomic factors such as crowding, lower income, day-care attendance, multiple siblings, and exposure to passive smoke within 6 months of onset of the RSV infection (89). Immunity to RSV infection is incomplete, variable, and not durable. In a day-care study, $98 \%$ of children were infected with a first RSV exposure (88), $74 \%$ became infected or reinfected after a second RSV exposure, and $65 \%$ became infected or reinfected after a third RSV exposure. Transmission of RSV occurs with inoculation of the nose or eyes, and less efficiently through the mouth. The incubation period is 2 to 8 days (90-92). Respiratory syncytial virus infection is confined to the respiratory tract-the upper respiratory tract in early disease and the lower respiratory tract in late disease.

The pathogenesis of RSV infection involves the spread and destruction of ciliated epithelial cells of the respiratory tract (Fig. 6.5), and lymphocytic peribronchiolar infiltration with edema of the walls and surrounding tissue, which leads to proliferation and necrosis of the bronchiole epithelium (93). The pulmonary epithelium responds to injury by the production of opsonins, collectins, and multiple chemokines and cytokines such as IL-1 $\beta$, IL-6, IL-8, IL-10, IL-11, RANTES, and macrophage inflammatory protein-1 $\alpha$ (MIP-1 $\alpha)$ (94). The production of chemokines and cytokines results in recruitment of effector molecules, neutrophils, macrophages, natural killer cells, and eosinophils. The bronchiole lumina become obstructed from inflammation, necrotic epithelium, and the secretion of mucus. Hyperinflation results from lumen narrowing with positive expiratory pressure. Atelectasis develops with complete obstruction and absorbed trapped air. Bronchiolitis results when an increase in lung volume and expiratory resistance occurs (95). Pneumonia results from an interstitial infiltration of mononuclear cells with an accompanied edema, and necrosis leads to alveolar filling (93).

Although antibodies to RSV does not prevent viral replication in the nasal passages, serum

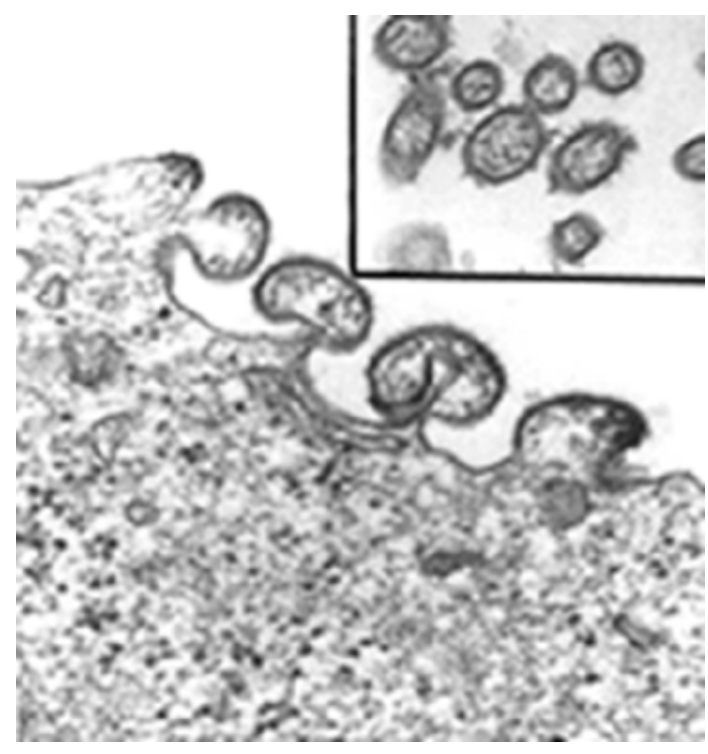

Figure 6.5. Electron microscopy of respiratory syncytial virus budding at the host cell membrane. (From www.epidemic.org/theFACTS/viruses/ viralReplication.html.)

antibody to specific RSV proteins has been associated with protection against RSV infection and provides the rationale for administration of RSV hyperimmune globulin and monoclonal antibody to infected persons with more severe RSV disease (94). The qualitative and quantitative antibody responses to the $\mathrm{F}$ and $\mathrm{G}$ proteins of RSV are not well defined but appear to correlate with resistance to reinfection and are influenced by the presence of preexisting antibody and age of the host $(95,96)$. Immunoglobulin M, IgG, IgE, and IgA are found in nasal secretions of persons infected with RSV (97). Immunoglobulin M appears early in RSV infection. An IgE and histamine response in nasopharynx secretions is associated with wheezing during acute illness and episodes of airway bronchospasm. IgA appears to be correlated with diminished titers of the virus.

Cell-mediated immunity is important in the clearance of RSV and recovery of the host. Immunosuppressed individuals with deficiencies of cellular immunity have more severe disease and prolonged shedding of virus (98). Patients have depressed lymphocyte function in T-cell subsets, depressed IL-12 levels and elevated IL-8 levels (99). Cytotoxic T lymphocyte (CTL) responses in persons infected with RSV are complex. In some studies, CTL and helper T lymphocyte responses are correlated with clini- 
cal response and viral clearance. The response to RSV infection is likely a result of both a helper $\mathrm{T}$ cell with both a Th1 response and a Th2 response (100). The quantity, timing, specificity, and types of $\mathrm{T}$ cells determine the immunologic and clinical outcomes of RSV infection.

The clinical manifestations of RSV infection vary by age and the presence of underlying diseases of the host. The major clinical manifestations associated with RSV infection include bronchiolitis, pneumonia, croup, otitis media, apnea, and sudden infant death syndrome. In infants and children under 1 year of age, infection with RSV is the most common cause of lower respiratory tract infection and upper respiratory tract illness $(101,102)$. Up to $2 \%$ of young children with first-time RSV infection require hospitalization. The majority of children hospitalized for RSV infection are under 6 months of age (102). Symptoms include wheezing, rhonchi, rales, rhinorrhea, nasal congestion, cough, low-grade fever, dyspnea, and hypoxemia (103). Hypoxemia represents lower respiratory tract involvement and diffuse viral involvement of the lung parenchyma (104). The mean arterial oxygen saturation on admission of one group of hospitalized infants was $87 \%$. Otitis media is a common complication of RSV infection in young children. In infants who are preterm or have low birth weight $(<2500 \mathrm{~g})$ or children with underlying diseases such as chronic lung disease, congenital heart disease, immunosuppressive conditions (i.e., those undergoing transplantation of bone marrow and solid organs, HIV), or other chronic diseases, RSV infection can result in complications with prolonged morbidity and mortality. In older children and adults, the clinical manifestation of RSV infection depends on the immune status of the host. In this older population, an infection with RSV represents a reinfection. In healthy individuals, reinfections with RSV are milder and range from being asymptomatic to causing upper respiratory tract illness such as nasal congestion, cough, hoarseness, sore throat, low-grade fever, and conjunctivitis. The average duration of clinical illness is 9.5 days and for viral shedding it is 1 to 6 days. In persons with medical conditions, especially those with underlying cardiac and pulmonary disease, the disease may be quite severe (105). Respiratory syncytial virus is a cause of cardiovascular and chronic obstructive pulmonary disease exacerbations, especially among individuals who are institutionalized.
Diagnosis of RSV depends on clinical suspicion and is confirmed by viral isolation (Fig. 6.6), detection of viral antigens or viral RNA, or serology. Isolation of RSV is time-consuming and expensive. Respiratory syncytial virus is isolated from nasopharyngeal washes, tracheal secretions, or nasal swabs. Specific cytopathic change is usually seen within 3 to 7 days. The shell vial technique hastens the identification of RSV (106). Antigen detection tests are rapid and less expensive and are used by most clinical laboratories. Available antigen detection tests include direct and indirect immunofluorescent assays, and an enzyme immunoassay (EIA) method (sensitivity $60-70 \%$ and specificity $90-95 \%$ ) (107). Reverse transcriptase PCR consistently has higher sensitivity and specificity rates than other diagnostic tools but is used mainly in research laboratories $(107,108)$. Serologic diagnosis of RSV is usually done using enzyme immunoassays and neutralizing assays. Serologic tests for RSV infection have been used in epidemiologic studies, but are not always practical in patient management due to the delay in acquiring convalescent sera. Also, production of a significant rise in antibody titer does not always occur especially in young infants and individuals with underlying medical conditions.

Treatment of most patients with mild disease is supportive, including adequate fluid intake, acetaminophen to reduce fever, and rest. Hospitalized infants may require oxygen therapy and sometimes mechanical ventilation and aerosolized ribavirin, bronchodilating agents, and corticosteroids (109). Aerosolized

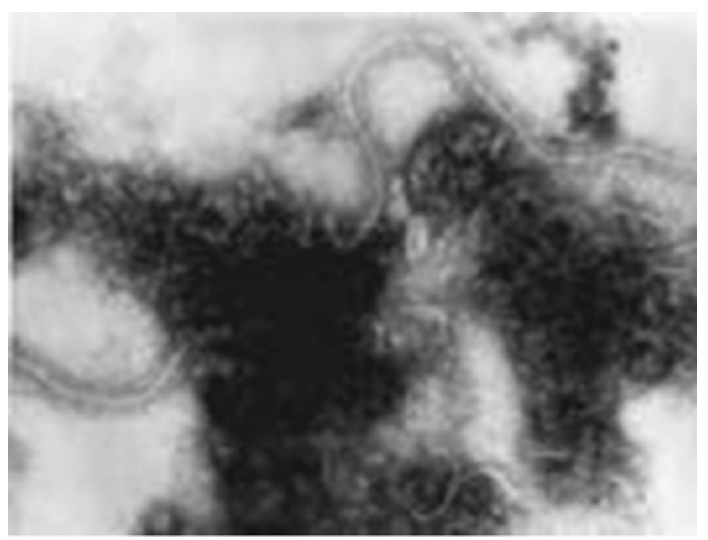

Figure 6.6. Electron microscopy of respiratory syncytial virus. (From www.cdc.gov/ncidod/aip/images/rsv_germ.jpg.) 
ribavirin is an approved antiviral therapy for RSV lower respiratory tract disease in hospitalized infants. Studies have shown that this broad-spectrum antiviral agent may reduce long-term pulmonary sequelae and recurrent wheezing and result in rapid improvement in clinical illness and oxygenation $(110,111)$. Bronchodilators and corticosteroids have been of benefit in infants with bronchiolitis. The use of RSV-neutralizing antibody [RSV-intravenous immunoglobulin (IVIG) polyclonal antibody] or intramuscular monoclonal antibody (palivizumab-humanized mouse IgG monoclonal antibody that binds the $\mathrm{F}$ protein of RSV) has been shown to reduce the risk of hospitalization in $41 \%$ to $50 \%$ of high-risk children with prematurity with or without chronic lung disease. RSV-IVIG may also be beneficial in the treatment of patients with compromised immune systems (112).

\section{Pulmonary Mucosal Immunity}

The pulmonary defense system includes the anatomic and mechanical barriers of the respiratory tract and mucosal immunity. These barriers form a first line of defense against mucosal transmitted pathogens. Most particles are filtered out of the inhaled air by the mouth and nose. Small particles $(<4 \mu \mathrm{m}$ in diameter) can travel to the lower respiratory tract. Mechanical barriers and reflex mechanisms (coughing and sneezing) prevent and reduce the amount of inhaled pathogens in the respiratory tract. The mucosal defense system consists of both innate barriers such as mucus, epithelium, and innate immune mechanisms (phagocytic cells), and adaptive host immunity, which consists of humoral and cell-mediated immunity such as secretory immunoglobulin A, CD4 T cells, and antigen-specific cytotoxic T lymphocytes (113).

The conducting airways, made up of the trachea and bronchi, are lined with ciliated columnar epithelial cells, which secrete antimicrobial factors and clear mucus, and generate inflammatory chemokines and cytokines that attract inflammatory and phagocytic cells into the lung. There are three types of epithelial cells: type I, type II and Clara cells. Type I cells are alveolar epithelial cells responsible for gas exchange. Type II cells produce a surface airway liquid that contains lysozyme, lactoferrin, secretory leukocyte proteinase inhibitor, catheli- cidins, and $\beta$-defensins, nitric oxide and extracellular superoxide dismutase all of which posses microbicidal activity $(114,115)$. Clara cells are localized in the bronchiole and involved in lung remodeling. The $\beta$-defensins may function as nonspecific immune lung host response and in communicating with memory $\mathrm{T}$ cells and dendritic cells. In the lower respiratory tract, humoral and cell-mediated host defenses play an important role in pulmonary mucosal immunity. Like the conducting airways, a surface airway liquid is present that lines the alveoli, and this microbicidal liquid contains surfactant, fibronectin, immunoglobulin, complement factors, free fatty acid, and iron-binding proteins. From an immunology point of view, surfactant, which has several components, serves to increase the microbicidal capacity of macrophages, affect free-radical production and lymphocyte activity, and bind various microorganisms including viruses (113). Binding microorganisms with surfactant may result in reduced microbial virulence or enhanced phagocytosis by neutrophils and alveolar macrophages (116).

The respiratory tract is made up of phagocytic cells, which include the alveolar macrophage, interstitial macrophage, dendritic cells, and intravascular macrophage (117). The alveolar macrophages are located in the alveolar lining fluid and defend the lower airways from inspired foreign materials (118). Alveolar macrophages are drawn into the lung when epithelial cells and resident macrophages produce chemokines such as macrophage inflammatory protein-1 (MIP-1), MIP-2, and macrophage chemoattractant protein-1 (MCP-1). The alveolar macrophages function by phagocytosing and eliminating organisms, and becoming a mediator of an inflammatory response recruiting neutrophils through the production of cytokines and chemokines (119). The interstitial macrophages are located in the connective tissue of the lung and serve as a phagocytic cell and a class II antigen presenting cell. Compared to alveolar macrophages, interstitial macrophages do not demonstrate Fc-receptor-independent phagocytosis, cytokine production, or oxygen radical production. Dendritic cells are located within the epithelium of the trachea, conducting airways, terminal airways, alveolar septa, pulmonary vasculature, and visceral pleura, and also serve as phagocytic cells and a class II antigen presenting cell. These cells are derived 
from monocytes and migrate to lymphoid tissue and stimulate T-cell immune responses. Dendritic cells are also capable of the production of a variety of chemokines and cytokines that stimulate both T-cell and B-cell immune responses (119). Intravascular macrophages are located in the capillary endothelial cells and they serve as phagocytic cells and remove foreign or damaged material entering the lung through the bloodstream.

The recruitment of neutrophils, occurring by chemokine and cytokine mediation, is vital to the inflammatory response in the lung. Complement factors, specifically the fifth component of complement, leukotriene $\mathrm{B}_{4}$, and peptides of bacterial cell walls are also responsible for eliciting mediators of inflammation and recruitment of neutrophils into areas of inflammation. These mediators are responsible for attracting and maintaining neutrophils to areas of lung injury as well as regulating the inflammatory process involved. Key chemokine and cytokines involved in this process include IL-1, tumor necrosis factor- $\alpha$ (TNF- $\alpha)$, IFN- $\gamma$, IL-8, IL-10, IL-12, and $\alpha$-chemokines (120).

The lung epithelium produces antibody through humoral immunity to prevent bacterial adherence or growth. The humoral immunity of the respiratory tract involves secretory immunoglobulin (sIgA), IgG, and IgM. Secretory $\operatorname{IgA}$ is a major immunoglobulin involved in the humoral immunity of the respiratory tract, and it provides an important first line of defense against the invasion of deeper tissues by respiratory tract viruses. It prevents or reduces the attachment of respiratory viruses and thus prevents internalization of host cells. Polymeric IgA has also been shown to neutralize virus intracellularly, and the transport of polymeric IgA (pIgA) across epithelial cells allows active elimination of immune complexes at mucosal sites and even virus inside epithelial cells. Many live attenuated viral vaccines optimize the production of sIgA in forming mucosal immune protection to respiratory tract viruses. Secretory $\operatorname{Ig} A$ accounts for $10 \%$ of the total protein of nasal secretions and provides antibacterial and antiviral activity (121). Other immunoglobulins, IgG and $\operatorname{IgM}$, also provide antibacterial and antiviral activity and aid in bacterial opsonization, complement activation, agglutination, and neutralization activity. They enter upper and lower airways by the route of transudation from the blood. Deficiencies in either $\operatorname{IgG}_{2}$ or $\mathrm{IgG}_{4}$ are associated with bronchiectasis, a progressive dilation of the bronchi or bronchioles, as a consequence of inflammation.

The cell-mediated immunity of the respiratory tract, as manifested by $\mathrm{CD} 4^{+} \mathrm{Th} 1$ cells and $\mathrm{CD}^{+}$cytotoxic $\mathrm{T}$ lymphocytes, is especially important against viruses and intracellular parasites because these organisms can survive within pulmonary macrophages. The CD4 to CD8 ratio is approximately $2: 1$. There is an estimated $4 \times 10^{8}$ lymphocytes on the epithelial surface of the human lung and more than $95 \%$ are T cells. T cells outnumber B cells by 10:1 in the lung. The lung has lymphoid tissue, located in follicles along the bronchial tree in bronchusassociated lymphoid tissue (BALT) and nasalassociated lymphoid tissue (NALT) commonly in the upper respiratory tract, tonsils, and adenoids, where uncommitted cells to memory $\mathrm{T}$ and B cells exist and differentiate (122). The pulmonary mucosal immune system allows for production of specific immune effectors that promote the removal or elimination of any viral pathogen that challenges the respiratory mucosa without damaging the mucosal surface or impairing gas exchange. The BALT, similar to the gut-associated lymphoid tissue of the intestinal tract, is intimately involved with the pulmonary mucosa and is considered the site where antigen presentation to $\mathrm{T}$ cells occurs before clonal expansion. Inhaled antigens that cross the respiratory epithelia surface encounter the antigen processing cells where $\mathrm{B}$ and $\mathrm{T}$ lymphocytes, in the BALT, are stimulated to become memory and effector cells. The increased memory T-cell numbers result in local proliferation or migration of these cells from the BALT. The memory lymphocytes are located in the submucosa and lamina propria. The lymphocytes are made up mostly of T cells of which $40 \%$ are CD4 cells (helper) and up to 32\% represent CD8 cells (suppressor) (123). Pulmonary lymphocytes migrate between lymphoid tissue and lung parenchyma. The effector cells are located between epithelial cells and in the interstitium of the lung. The cytotoxic T lymphocytes are present in the pulmonary mucosa.

Inhaled antigens that reach the alveolus encounter antigen-presenting cells, which activate alveolar lymphoid cells. Activated alveolar lymphoid cells stimulate memory lymphocytes to migrate to areas of inflammation, which results in a localized accumulation of antigenspecific $T$ and $B$ lymphocytes. The critical step 
in this inflammatory process is the binding of $\mathrm{T}$ cells to endothelium via the interaction of leukocyte function-associated antigen-1 integrins on the lymphocyte cell surface with endothelium ligands such as ICAM-1 and -2 and vascular cell adhesion molecule-1. Ligands on the endothelium are expressed via the upregulation of inflammatory mediators IL-1, IFN- $\gamma$, and TNF- $\alpha$. Activated lymphocytes function by producing antibody, having cytotoxic activity, or producing inflammatory mediators. Cytotoxic cells within the lung, including natural killer cells, antibody-dependent cytotoxic cells, and antigen-restricted cytotoxic cells, can produce cytokines when they interact with pathogens. Unstimulated T lymphocytes produce IL-2 and memory $\mathrm{T}$ lymphocytes are able to produce Th1 and Th2 pattern of cytokines. A Th1 immune response involves cell-mediated inflammatory reactions with the production of cytokines such as IFN- $\gamma$, IL-2, IL-6, and IL-10. A Th2 immune response involves humoral immunity with cytokine production such as IL-4, IL-5, and IL10 and antibody production. Other cytokines may be secreted by both a Th1 and Th2 immune response such as TNF- $\alpha$, IL-3, and granulocytemacrophage colony-stimulating factor. Stimulated alveolar epithelial cells express a variety of integrins such as ICAM-1 that allow the infiltration and retention of lymphocytes, leukocytes, and monocytes.

\section{Conclusion}

Respiratory viruses, such as adenovirus, SARS$\mathrm{CoV}$, influenzavirus, rhinovirus, and respiratory syncytial virus, are common causes of pulmonary and nonpulmonary clinical syndromes. These viruses are a significant cause of morbidity and mortality worldwide. The pulmonary defense has the difficult task of balancing the ability to destroy or remove the constant barrage of foreign antigens that assault our mucosal tissues without causing undue and injurious inflammation. Pulmonary mucosal immunity consists of both innate and acquired immunity, which are essential in protecting the host from developing a respiratory tract illness. Specifically, humoral immunity (B cells and immunoglobulin) and cell-mediated immunity (antigen-presenting cells and T cells) are vital to protecting the host against respiratory viruses. It is these protective mechanisms that defend the pulmonary mucosa from colonization and invasion by viral pathogens and keep most people healthy despite a continuous barrage of inhaled pathogens and particulates.

\section{References}

1. Rowe WP, Huebner RJ, Gilmore LK, Parrott RH, Ward TG. Isolation of a cytopathogenic agent from human adenoids undergoing spontaneous degeneration in tissue culture. Proc Soc Exp Biol Med 1953;84(3): 570-573.

2. De Jong JC, Wermenbol AG, Verweij-Uijterwaal MW, et al. Adenoviruses from human immunodeficiency virus-infected individuals, including two strains that represent new candidate serotypes Ad50 and Ad51 of species B1 and D, respectively. J Clin Microbiol 1999;37(12):3940-3945.

3. Jennings LC, Anderson TP, Werno AM, Beynon KA and Murdoch DR. Viral etiology of acute respiratory tract infections in children presenting to hospital: role of polymerase chain reaction and demonstration of multiple infections. Pediatr Infect Dis J 2004;23(11): 1003-1007.

4. Hilleman MR, Werner JH. Recovery of new agent from patients with acute respiratory illness. Proc Soc Exp Biol Med 1954;85(1):183-188.

5. Shenk T. Adenoviridae: The viruses and their replication. In: Fields BN, Knipe DM, Howley PM, eds. Virology, 3rd ed. Philadelphia: Lippincott-Raven, 1996: 2111-2148.

6. Huebner RJ, Rowe WP, Lane WT. Oncogenic effects in hamsters of human adenovirus types 12 and 18. Proc Natl Acad Sci USA 1962;48:2051-2058.

7. Krafft AE, Russell KL, Hawksworth AW, et al. Evaluation of PCR testing of ethanol-fixed nasal swab specimens as an augmented surveillance strategy for influenza virus and adenovirus identification. J Clin Microbiol 2005;43(4):1768-1775.

8. Schievning M, Buxbavm-Conradi H, Jager G, Kolb HJ. Intravenous ribavirin for eradication of respiratory syncytial virus (RSV) and adenovirus isolates from respiratory and/or gastrointestinal tract in recipients of allogeneic hematopoietic stem cell transplants. Hematol J. 2004;5(2):135-144.

9. Dagan R, Schwartz RH, Insel RA, Menegus MA. Severe diffuse adenovirus 7a pneumonia in a child with combined immunodeficiency: possible therapeutic effect of human immune serum globulin containing specific neutralizing antibody. Pediatr Infect Dis 1984;3(3): 246-251.

10. Legrand F, Berrebi D, Houhou N, et al. Early diagnosis of adenovirus infection and treatment with cidofovir after bone marrow transplantation in children. Bone Marrow Transplant 2001;27(6):621-626.

11. Tyrrell DA, Bynoe ML. Cultivation of a novel type of common-cold virus in organ cultures. Br Med J 1965; 5448:1467-1470.

12. Hamre D, Connelly AP Jr, Procknow JJ. Virologic studies of acute respiratory disease in young adults. IV. Virus isolations during four years of surveillance. Am J Epidemiol 1966;83(2):238-249. 
13. Hamre D, Procknow JJ. A new virus isolated from the human respiratory tract. Proc Soc Exp Biol Med 1966; 121(1):190-193.

14. Ksiazek TG, Erdman D, Goldsmith CS, et al. A novel coronavirus associated with severe acute respiratory syndrome. N Engl J Med 2003;348(20):19531966.

15. Heath RB. The pathogenesis of respiratory viral infection. Postgrad Med J 1979;55(640):122-127.

16. Sakai K, Kawaguchi Y, Kishino Y, Kido H. Electron immunohistochemical localization in rat bronchiolar epithelial cells of tryptase Clara, which determines the pneumotropism and pathogenicity of Sendai virus and influenza virus. J Histochem Cytochem 1993; 41(1):89-93.

17. Sakai K, Kohri T, Tashiro M, Kishino Y, Kido H. Sendai virus infection changes the subcellular localization of tryptase Clara in rat bronchiolar epithelial cells. Eur Respir J 1994;7(4):686-692.

18. Bradburne AF, Bynoe ML, Tyrrell DA. Effects of a "new" human respiratory virus in volunteers. Br Med J 1967;3(568):767-769.

19. Lew TW, Kwek TK, Tai D, et al. Acute respiratory distress syndrome in critically ill patients with severe acute respiratory syndrome. JAMA 2003;290(3):374380.

20. Cheung CY, Poon LL, Ng IH, et al. Cytokine responses in severe acute respiratory syndrome coronavirusinfected macrophages in vitro: possible relevance to pathogenesis. J Virol 2005;79(12):7819-7826.

21. Donnelly CA, Ghani AC, Leung GM, et al. Epidemiological determinants of spread of causal agent of severe acute respiratory syndrome in Hong Kong. Lancet 2003;361(9371):1761-1766.

22. Lee $\mathrm{N}$, Hui $\mathrm{D}, \mathrm{Wu} \mathrm{A}$, et al. A major outbreak of severe acute respiratory syndrome in Hong Kong. N Engl J Med 2003;348(20):1986-1994.

23. Myint S, Johnston S, Sanderson G, Simpson H. Evaluation of nested polymerase chain methods for the detection of human coronaviruses 229E and OC43. Mol Cell Probes 1994;8(5):357-364.

24. Lina B, Valette M, Foray S, et al. Surveillance of community-acquired viral infections due to respiratory viruses in Rhone-Alpes (France) during winter 1994 to 1995. J Clin Microbiol 1996;34(12):30073011.

25. Peiris JS, Chu CM, Cheng VC, et al. Clinical progression and viral load in a community outbreak of coronavirus-associated SARS pneumonia: a prospective study. Lancet 2003;361(9371):1767-1772.

26. Zhao Z, Zhang F, Xu M, et al. Description and clinical treatment of an early outbreak of severe acute respiratory syndrome (SARS) in Guangzhou, PR China. J Med Microbiol 2003;52(pt 8):715-720.

27. Sydenham T. Classical Descriptions of Disease. London: R. Wellington, 1955.

28. Thomson D, Thomson R. Influenza. New York: Ann Pickett-Thomas Research Labs, 1933.

29. Crosby AW. Epidemic and Peace, 1918. Part IV. Westport, CT: Greenwood Press, 1976.

30. Glezen WP, Keitel WA, Taber LH, Piedra PA, Clover RD, Couch RB. Age distribution of patients with medically-attended illnesses caused by sequential variants of influenza A/H1N1: comparison to agespecific infection rates, 1978-1989. Am J Epidemiol 1991;133(3):296-304.
31. Barker WH, Mullooly JP. Impact of epidemic type A influenza in a defined adult population. Am J Epidemiol 1980;112(6):798-811.

32. Wilson IA, Cox NJ. Structural basis of immune recognition of influenza virus hemagglutinin. Annu Rev Immunol 1990;8:737-771.

33. Alford RH, Kasel JA, Gerone PJ, Knight V. Human influenza resulting from aerosol inhalation. Proc Soc Exp Biol Med 1966;122(3):800-804.

34. Little JW, Douglas RG Jr, Hall WJ, Roth FK. Attenuated influenza produced by experimental intranasal inoculation. J Med Virol 1979;3(3):177-188.

35. Hemmes JH, Winkler KC, Kool SM. Virus survival as a seasonal factor in influenza and poliomyelitis. Nature 1960;188:430-431.

36. Katze MG, Krug RM. Metabolism and expression of RNA polymerase II transcripts in influenza virus-infected cells. Mol Cell Biol 1984;4(10):21982206.

37. Katze MG, DeCorato D, Krug RM. Cellular mRNA translation is blocked at both initiation and elongation after infection by influenza virus or adenovirus. J Virol 1986;60(3):1027-1039.

38. Sanz-Ezquerro JJ, de la Luna S, Ortin J, Nieto A. Individual expression of influenza virus PA protein induces degradation of coexpressed proteins. J Virol 1995;69(4):2420-2426.

39. Larson HE, Parry RP, Tyrrell DA. Impaired polymorphonuclear leucocyte chemotaxis after influenza virus infection. Br J Dis Chest 1980;74(1):56-62.

40. Roberts NJ Jr, Steigbigel RT. Effect of in vitro virus infection on response of human monocytes and lymphocytes to mitogen stimulation. J Immunol 1978;121(3):1052-1058.

41. Mozdzanowska K, Furchner M, Zharikova D, Feng J, Gerhard W. Roles of CD4+ T-cell-independent and -dependent antibody responses in the control of influenza virus infection: evidence for noncognate CD4+ T-cell activities that enhance the therapeutic activity of antiviral antibodies. J Virol 2005;79(10): 5943-5951.

42. Murphy BR, Nelson DL, Wright PF, Tierney EL, Phelan MA, Chanock RM. Secretory and systemic immunological response in children infected with live attenuated influenza $A$ virus vaccines. Infect Immun 1982;36(3):1102-1108.

43. Murphy BR, Kasel JA, Chanock RM. Association of serum anti-neuraminidase antibody with resistance to influenza in man. N Engl J Med 1972;286(25): 1329-1332.

44. Schulman JL, Khakpour M, Kilbourne ED. Protective effects of specific immunity to viral neuraminidase on influenza virus infection of mice. J Virol 1968;2(8): $778-786$.

45. Kilbourne ED, Laver WG, Schulman JL, Webster RG. Antiviral activity of antiserum specific for an influenza virus neuraminidase. J Virol 1968;2(4): 281-288.

46. Wagner DK, Clements ML, Reimer CB, Snyder M, Nelson DL, Murphy BR. Analysis of immunoglobulin $\mathrm{G}$ antibody responses after administration of live and inactivated influenza A vaccine indicates that nasal wash immunoglobulin $\mathrm{G}$ is a transudate from serum. J Clin Microbiol 1987;25(3):559-562.

47. Lamb JR, Eckels DD, Lake P, Woody JN, Green N. Human T-cell clones recognize chemically synthe- 
sized peptides of influenza haemagglutinin. Nature 1982;300(5887):66-69.

48. Lamb JR, Woody JN, Hartzman RJ, Eckels DD. In vitro influenza virus-specific antibody production in man: antigen-specific and HLA-restricted induction of helper activity mediated by cloned human T lymphocytes. J Immunol 1982;129(4):1465-1470.

49. Hashimoto G, Wright PF, Karzon DT. Antibodydependent cell-mediated cytotoxicity against influenza virus-infected cells. J Infect Dis 1983;148(5): 785-794.

50. McMichael AJ, Gotch FM, Noble GR, Beare PA. Cytotoxic T-cell immunity to influenza. N Engl J Med 1983; 309(1):13-17.

51. Newton DW, Mellen CF, Baxter BD, Atmar RL, Menegus MA. Practical and sensitive screening strategy for detection of influenza virus. J Clin Microbiol 2002;40(11):4353-4356.

52. Covalciuc KA, Webb KH, Carlson CA. Comparison of four clinical specimen types for detection of influenza $\mathrm{A}$ and $\mathrm{B}$ viruses by optical immunoassay (FLU OIA test) and cell culture methods. J Clin Microbiol 1999; 37(12):3971-3974.

53. Noyola DE, Clark B, O'Donnell FT, Atmar RL, Greer J, Demmler GJ. Comparison of a new neuraminidase detection assay with an enzyme immunoassay, immunofluorescence, and culture for rapid detection of influenza A and B viruses in nasal wash specimens. J Clin Microbiol 2000;38(3):1161-1165.

54. Habib-Bein NF, Beckwith WH 3rd, Mayo D, Landry ML. Comparison of SmartCycler real-time reverse transcription-PCR assay in a public health laboratory with direct immunofluorescence and cell culture assays in a medical center for detection of influenza $\mathrm{A}$ virus. J Clin Microbiol 2003;41(8):3597-3601.

55. Landry ML, Ferguson D. Suboptimal detection of influenza virus in adults by the Directigen Flu $A+B$ enzyme immunoassay and correlation of results with the number of antigen-positive cells detected by cytospin immunofluorescence. J Clin Microbiol 2003; 41(7):3407-3409.

56. Centers for Disease Control and Prevention. Prevention and control of influenza. Part I: antiviral agents. MMWR 1994;43:1.

57. Hayden FG, Belshe RB, Clover RD, Hay AJ, Oakes MG, Soo W. Emergence and apparent transmission of rimantadine-resistant influenza A virus in families. N Engl J Med 1989;321(25):1696-1702.

58. Belshe RB, Burk B, Newman F, Cerruti RL, Sim IS. Resistance of influenza $A$ virus to amantadine and rimantadine: results of one decade of surveillance. J Infect Dis 1989;159(3):430-435.

59. Ziegler T, Hemphill ML, Ziegler ML, et al. Low incidence of rimantadine resistance in field isolates of influenza A viruses. J Infect Dis 1999;180(4):935939.

60. Bui M, Whittaker G, Helenius A. Effect of M1 protein and low $\mathrm{pH}$ on nuclear transport of influenza virus ribonucleoproteins. J Virol 1996;70(12):8391-8401.

61. Air GM, Ritchie LR, Laver WG, Colman PM. Gene and protein sequence of an influenza neuraminidase with hemagglutinin activity. Virology 1985;145(1): 117-122.

62. Colman PM, Ward CW. Structure and diversity of influenza virus neuraminidase. Curr Top Microbiol Immunol 1985;114:177-255.
63. Kruse W. Die Erreger con Husten and Schupfen. Munchen Med Wochenschr 1914;61:1547.

64. Andrewes C. The Common Cold. New York: W.W. Norton, 1965.

65. Hayflick L, Moorhead PS. The serial cultivation of human diploid cell strains. Exp Cell Res 1961;25: 585-621.

66. Hamparian VV, Colonno RJ, Cooney MK, et al. A collaborative report: rhinoviruses-extension of the numbering system from 89 to 100 . Virology 1987; 159(1):191-192.

67. Gwaltney JM Jr, Hendley JO, Simon G, Jordan WS Jr. Rhinovirus infections in an industrial population. I. The occurrence of illness. N Engl J Med 1966;275(23): 1261-1268.

68. Halperin SA, Eggleston PA, Hendley JO, Suratt PM, Groschel DH, Gwaltney JM Jr. Pathogenesis of lower respiratory tract symptoms in experimental rhinovirus infection. Am Rev Respir Dis 1983;128(5): 806-810.

69. Winther B, Greve JM, Gwaltney JM Jr, et al. Surface expression of intercellular adhesion molecule 1 on epithelial cells in the human adenoid. J Infect Dis 1997;176(2):523-525.

70. Monto AS. A community study of respiratory infections in the tropics. 3. Introduction and transmission of infections within families. Am J Epidemiol 1968;88(1):69-79.

71. Monto AS, Johnson KM. A community study of respiratory infections in the tropics. II. The spread of six rhinovirus isolates within the community. Am J Epidemiol 1968;88(1):55-68.

72. Forsyth BR, Bloom HH, Johnson KM, Chanock RM. Patterns of illness in rhinovirus infections of military personnel. N Engl J Med 1963;269:602-606.

73. Karim YG, Ijaz MK, Sattar SA, Johnson-Lussenburg $\mathrm{CM}$. Effect of relative humidity on the airborne survival of rhinovirus-14. Can J Microbiol 1985;31(11): 1058-1061.

74. Makela MJ, Puhakka T, Ruuskanen O, et al. Viruses and bacteria in the etiology of the common cold. J Clin Microbiol 1998;36(2):539-542.

75. Pereira MS, Andrews BE, Gardner SD. A study on the virus aetiology of mild respiratory infections in the primary school child. J Hyg (Lond) 1967;65(4):475483.

76. Douglas RG Jr, Cate TR, Gerone PJ, Couch RB. Quantitative rhinovirus shedding patterns in volunteers. Am Rev Respir Dis 1966;94(2):159-167.

77. Doyle WJ, Boehm S, Skoner DP. Physiologic responses to intranasal dose-response challenges with histamine, methacholine, bradykinin, and prostaglandin in adult volunteers with and without nasal allergy. J Allergy Clin Immunol 1990;86:924-935.

78. Rossen RD, Douglas G Jr, Cate TR, Couch RB, Butler WT. The sedimentation behavior of rhinovirus neutralizing activity in nasal secretion and serum following the rhinovirus common cold. J Immunol 1966;97(4):532-538.

79. Cate TR, Rossen RD, Douglas RG Jr, Butler WT, Couch $\mathrm{RB}$. The role of nasal secretion and serum antibody in the rhinovirus common cold. Am J Epidemiol 1966;84(2):352-363.

80. Johnston SL, Sanderson G, Pattemore PK, et al. Use of polymerase chain reaction for diagnosis of picornavirus infection in subjects with and without 
respiratory symptoms. J Clin Microbiol 1993;31(1): 111-117.

81. Turner RB. New considerations in the treatment and prevention of rhinovirus infections. Pediatr Ann 2005; 34(1):53-57.

82. Blount RE Jr, Morris JA, Savage RE. Recovery of cytopathogenic agent from chimpanzees with coryza. Proc Soc Exp Biol Med 1956;92(3):544-549.

83. Hall CB, Douglas RG Jr. Clinically useful method for the isolation of respiratory syncytial virus. J Infect Dis 1975;131(1):1-5.

84. Foy HM, Cooney MK, Maletzky AJ, Grayston JT. Incidence and etiology of pneumonia, croup and bronchiolitis in preschool children belonging to a prepaid medical care group over a four-year period. Am J Epidemiol 1973;97(2):80-92.

85. Peret TC, Hall CB, Hammond GW, et al. Circulation patterns of group A and B human respiratory syncytial virus genotypes in 5 communities in North America. J Infect Dis 2000;181(6):1891-1896.

86. Hambling MH. Survival of the respiratory syncytial virus during storage under various conditions. $\mathrm{Br} \mathrm{J}$ Exp Pathol 1964;45:647-655.

87. Shek LP, Lee BW. Epidemiology and seasonality of respiratory tract virus infections in the tropics. Paediatr Respir Rev 2003;4(2):105-111.

88. Henderson FW, Collier AM, Clyde WA Jr, Denny FW. Respiratory-syncytial-virus infections, reinfections and immunity. A prospective, longitudinal study in young children. N Engl J Med 1979;300(10):530534.

89. Holberg CJ, Wright AL, Martinez FD, Ray CG, Taussig LM, Lebowitz MD. Risk factors for respiratory syncytial virus-associated lower respiratory illnesses in the first year of life. Am J Epidemiol 1991;133(11): $1135-1151$.

90. Knight V, Kapikian AZ, Kravetz HM, et al. Ecology of a newly recognized common respiratory agent RS virus. Combined clinical staff conference at the National Institutes of Health. Ann Intern Med 1961; 55:507-524.

91. Johnson KM, Chanock RM, Rifkind D, Kravetz HM, Knight V. Respiratory syncytial virus. IV. Correlation of virus shedding, serologic response, and illness in adult volunteers. JAMA 1961;176:663-667.

92. Kravetz HM, Knight V, Chanock RM, et al. Respiratory syncytial virus. III. Production of illness and clinical observations in adult volunteers. JAMA 1961;176:657663.

93. Aherne W, Bird T, Court SD, Gardner PS, McQuillin J. Pathological changes in virus infections of the lower respiratory tract in children. J Clin Pathol 1970; 23(1):7-18

94. Graham BS, Johnson TR, Peebles RS. Immunemediated disease pathogenesis in respiratory syncytial virus infection. Immunopharmacology 2000; 48(3):237-247.

95. Wohl ME, Stigol LC, Mead J. Resistance of the total respiratory system in healthy infants and infants with bronchiolitis. Pediatrics 1969;43(4):495-509.

96. Crowe JE Jr. Immune responses of infants to infection with respiratory viruses and live attenuated respiratory virus candidate vaccines. Vaccine 1998;16: 1423-1432.

97. Munoz JL, McCarthy CA, Clark ME, Hall CB. Respiratory syncytial virus infection in C57BL/6 mice: clear- ance of virus from the lungs with virus-specific cytotoxic T cells. J Virol 1991;65(8):4494-4497.

98. Hall CB, Walsh EE, Long CE, Schnabel KC. Immunity to and frequency of reinfection with respiratory syncytial virus. J Infect Dis 1991;163(4):693-698.

99. Welliver RC. Immunology of respiratory syncytial virus infection: eosinophils, cytokines, chemokines and asthma. Pediatr Infect Dis J 2000;19(8):780-783.

100. Hall CB, Powell KR, MacDonald NE, et al. Respiratory syncytial viral infection in children with compromised immune function. N Engl J Med 1986;315(2): 77-81.

101. Abu-Harb M, Bell F, Finn A, et al. IL-8 and neutrophil elastase levels in the respiratory tract of infants with RSV bronchiolitis. Eur Respir J 1999;14(1):139143.

102. Fleming DM, Pannell RS, Elliot AJ, Cross KW. Respiratory illness associated with influenza and respiratory syncytial virus infection. Arch Dis Child 2005;90(7): 741-746.

103. Kotaniemi-Syrjanen A, Laatikainen A, Waris M, Reijonen TM, Vainionpaa R, Korppi M. Respiratory syncytial virus infection in children hospitalized for wheezing: virus-specific studies from infancy to preschool years. Acta Paediatr 2005;94(2):159-165.

104. Isaacs D, Bangham CR, McMichael AJ. Cell-mediated cytotoxic response to respiratory syncytial virus in infants with bronchiolitis. Lancet 1987;2(8562):769771.

105. Shay DK, Holman RC, Newman RD, Liu LL, Stout JW, Anderson LJ. Bronchiolitis-associated hospitalizations among US children, 1980-1996. JAMA 1999;282(15): 1440-1446.

106. Engler HD, Preuss J. Laboratory diagnosis of respiratory virus infections in 24 hours by utilizing shell vial cultures. J Clin Microbiol 1997;35(8):2165-2167.

107. Abels S, Nadal D, Stroehle A, Bossart W. Reliable detection of respiratory syncytial virus infection in children for adequate hospital infection control management. J Clin Microbiol 2001;39(9):3135-3139.

108. Falsey AR, Formica MA, Walsh EE. Diagnosis of respiratory syncytial virus infection: comparison of reverse transcription-PCR to viral culture and serology in adults with respiratory illness. J Clin Microbiol 2002;40(3):817-820.

109. Kimpen JL, Schaad UB. Treatment of respiratory syncytial virus bronchiolitis: 1995 poll of members of the European Society for Paediatric Infectious Diseases. Pediatr Infect Dis J 1997;16(5):479-481.

110. Edell D, Khoshoo V, Ross G, Salter K. Early ribavirin treatment of bronchiolitis: effect on long-term respiratory morbidity. Chest 2002;122(3):935-939.

111. Khoshoo V, Ross G, Edell D. Effect of interventions during acute respiratory syncytial virus bronchiolitis on subsequent long term respiratory morbidity. Pediatr Infect Dis J 2002;21(5):468-472.

112. American Academy of Pediatrics Committee on Infectious Diseases and Committee of Fetus and Newborn. Prevention of respiratory syncytial virus infections: indications for use of palivizumab and update on the use of RSV-IVIG. Pediatrics 1998;1:1211-1216.

113. Reynolds HY. Defense mechanisms against infections. Curr Opin Pulmon Med 1999;5(3):136-142.

114. Coonrod JD. Human alveolar lining material and antibacterial defenses. Am Rev Respir Dis 1986;134(6): 1337. 
115. Coonrod JD. The role of extracellular bactericidal factors in pulmonary host defense. Semin Respir Infect 1986;1(2):118-129.

116. Wright JR. Immunomodulatory functions of surfactant. Physiol Rev 1997;77(4):931-962.

117. Lohmann-Matthes ML, Steinmuller C, FrankeUllmann G. Pulmonary macrophages. Eur Respir J 1994;7(9):1678-1689.

118. Sibille Y, Reynolds HY. Macrophages and polymorphonuclear neutrophils in lung defense and injury. Am Rev Respir Dis 1990;141(2):471-501.

119. MacNee W, Selby C. Neutrophil kinetics in the lungs. Clin Sci 1990;79(2):97-107.

120. Luster AD. Chemokines-chemotactic cytokines that mediate inflammation. N Engl J Med 1998;338(7):436445.
121. Reynolds H. Normal and defective respiratory host defense mechanisms. In: Pennington JE, ed. Respiratory Infections: Diagnosis and Management, 2nd ed. New York: Raven, 1988:1-33.

122. Agostini C, Chilosi M, Zambello R, Trentin L, Semenzato G. Pulmonary immune cells in health and disease: lymphocytes. Eur Respir J 1993;6(9):13781401.

123. Fishman AP, Reynolds, HY, Elias JA, et al. Pulmonary defense mechanisms against infection. In: Fishman AP, ed. Fishman's Pulmonary Diseases and Disorders, 3rd ed. New York: McGraw-Hill, 1998:265-274. 